\title{
Diagnóstico y caracterización molecular de Mycosphaerella fijiensis mediante la técnica de amplificación aleatoria de polimorfismos (RAPD) y análisis de regiones transcriptos internos (ITS's)
}

\author{
${ }^{1}$ Chacín Zambrano Christian Andrei | 2 Ángel Díaz Jorge Evelio
}

Recibido:

Noviembre 20 de 2009

Aceptado: Octubre 12 de 2010

\section{Resumen}

A partir de la lámina foliar se obtuvieron 12 aislamientos de Mycosphaerella fijiensis provenientes de zonas plataneras y bananeras de Colombia, estableciendo cultivos monospóricos para purificar y evitar sobrelapamientos del hongo. Se extrajo el ADN a partir del micelio y tejido foliar infectado mediante el protocolo de Goodwin $\mathcal{E}$ Lee y Gilbertson $\mathcal{E}$ Dellaporta, obteniendo un ADN de buena calidad. Se amplificó la región ITS mediante iniciadores universales y específicos mostrando productos de amplificación de 233 pb para ITS A (iniciador $1+$ iniciador 2), una banda de 360 pb para el ITS B (iniciador 3 + iniciador 4), una banda de 593 pb para el ITS C (iniciador $1+$ iniciador 4) y un amplificado de 1080 pb con la combinación del iniciador específico MF 137 y R635. A la vez, se determinó la variabilidad genética por la técnica de RAPD's generando productos de amplificación entre 280 pb - 2115 pb y bandas comunes entre los aislamientos obtenidos. Se determinó una similaridad genética de los aislamientos de Norte de Santander y el aislamiento de Mérida en un 70\% con respecto a los de Santander, Antioquía con un 48\% y 35\% respectivamente.

Palabras clave: ITS's, Mycosphaerella fijiensis, RAPD, Sigatoka negra, cultivos monospóricos.

\section{Abstract}

Coming from the foliar sheet it was posible to obtain 12 Mycosphaerella fijiensis isolations originating from the plantain and banana zones of Colombia, establishing monosporic cultures to purify and to avoid overlapping of the fungus. The DNA was estracted from the mycelium and the foliar tissue infected by means of the protocol of Goodwin and Lee and Gilbertson and Dellaporta, by good quality was obtained. The ITS region was amplified though of universal and specific primers showing products of amplification of $233 \mathrm{pb}$ for the ITS A(primer $1+$ primer 2), a 360 pb band for the ITS B (primer $3+$ primer 4), a 593 pb band for the ITS C (primer $1+$ primer 4) and an amplification of 1080 pb with the combination of the specific MF 137 y R635 primers. Simultaneously the genetic variability by the RAPD technique was determined (a) Magíster en Biotecnolog los Microorganismos ULA- Mérida, Docente - Investigador Universidad christianchacin@gmail.com

${ }^{2}$ B. Sc, MSc., PhD. Coordinador del Laboratorio Nacional de Análisis Molecular ICA - Tibaitatá. jorgecol@gmail.com 
generating products of amplification between $280 \mathrm{pb}-2115 \mathrm{pb}$ and common bands between the obtained isolations. A genetic similarity was determined of the isolations of "Norte de Santander" in Colombia, and the isolation of "Mérida" in Venezuela, at 70\% in relation with those of "Santander" and "Antioquia" in Colombia with $48 \%$ and $35 \%$ each determined respectively.

Keywords: ITS 's, Mycosphaerella fijiensis, RAPD, Black Sigatoka, monosporic cultures.

\section{Introducción}

Al romperse los equilibrios naturales entre las plantas y sus enemigos, éstos han proliferado en forma alarmante, causando alteraciones en la fisiología y morfología de las plantas, obligando al hombre a tener una lucha continúa contra estos organismos vivos. Estas alteraciones pueden ser ocasionadas por bacterias, virus, nemátodos y principalmente por los hongos. Los hongos engloban una amplia variedad de formas reproductivas y de hábitos de vida (Agrios, 1996).

Aproximadamente existen 100.000 especies de hongos, que hasta el momento han sido descritas, los cuales, el hombre se ha preocupado por estudiar cerca de 8000 que son patogénicas a las plantas, y 100 que afectan al hombre (ICA Informa 25). Entre los hongos patogénicos que atacan las plantas, se encuentran una especie que afecta las plantaciones de plátano y banano. La sigatoka Negra causada por Mycosphaerella fijiensis, se han diseminado incontrolablemente en las regiones productoras del plátano y banano, donde son considerados como uno de los productos básicos de la dieta alimenticia de los países en desarrollo, este fruto, junto con las raíces y tubérculos, aportan el 40\% del total de la oferta de alimentos en términos de calorías (UniValle - UPEC 2001), siendo una fuente de ingresos importantes para las familias campesinas y de nuestro país.

El presente trabajo muestra como el diagnostico molecular, mediante técnicas basadas en PCR (Reacción en cadena de la polimerasa), los ITS's universales, ITS's específicos y RAPDs (Fragmentos polimórficos de DNA amplificado al Azar), son una herramienta útil para establecer una prueba estándar para la identificación de aislamientos y comparar la variabilidad genética del hongo causante de la Sigatoka Negra.

\section{Materiales y métodos}

Obtención del material vegetal. Las muestras con material infectado con Sigatoka negra se obtuvieron a partir de las recolecciones provenientes de zonas platanera y bananeras, donde se presentan los focos de la enfermedad. Las muestras a trabajar se envolvieron en papel periódico, teniendo en cuenta la identificación de cada una de ellas y guardadas a temperatura ambiente antes de enviarlas al Laboratorio de Análisis Molecular ICA - Tibaitatá.

Aislamiento del patógeno. Partiendo del material vegetal en su estado $5-6$ de infección, se procede a recortar varias lesiones sucesivas hasta completar el área de una caja de petri pequeña. Luego de ello se establece un ambiente óptimo para la descarga de las ascosporas en un tiempo estimado de 30 minutos para evitar contaminación con otros agentes. Las cajas de petri son inspeccionadas haciendo un barrido microscópico utilizando el objetivo 40X (Stover, 1962).

Posteriormente a su identificación y señalamiento, se procedió a cortar con una aguja de disección, de forma delicada el 
área de agar circundante a cada ascospora (Stover 1968). Se tomó cada fragmento de aproximadamente $2 \mathrm{~mm} 2$ con el fin de traspasar dichos cortes a una caja de medio de cultivo mycophil agar o V8 sólido (Ruiz, 1997).

Establecimiento de cultivos monospóricos. Una vez determinadas las características macroscópicas y microscópicas de cada uno de los aislamientos, se procedió a purificarlos, por medio de nuevo pases en PDA. Obtenida una única colonia o un número en el cual no existiera riesgo de sobrelapamiento en cada caja de petri, se procedió a realizar cultivos monospóricos que permitió garantizar la pureza del hongo. Para esto, se tomó como referencia la metodología propuesta por Lopez (2004).

\section{Extracción de ADN}

Para el cumplimiento de este objetivo, se planteó estandarizar metodologías de extracción de ADN a partir del micelio del hongo para construir un banco de germoplasma de este agente, y a partir del material vegetal para facilitar el diagnóstico del agente causal de la Sigatoka negra en sus diferentes estadios de la enfermedad. Para ello, se empleo el siguiente procedimiento:

Extracción a partir del micelio del hongo. Para la extracción de ADN total para Mycosphaerella fijiensis, se emplearon dos protocolos para obtener ADN de buena calidad: el protocolo de Goodwin and Lee en 1993 y Doyle and Doyle (1987) (Reportado Lopez, 2004).

Extracción a partir del material vegetal infectado. Para la estandarización del protocolo de extracción de ADN a partir del material vegetal infectado, se probaron dos metodologías reportadas en otras investigaciones para la extracción de ADN vegetal como son: El protocolo de Stewart, 1993 y el protocolo de Gilbertson and Dellaporta.

Ampliación de la región ITS mediante iniciadores universales. Para el método de diagnosis al nivel de ITS`s universales, se estandarizó el procedimiento de identificación para la amplificación de las regiones del rADN. (Tabla $\mathrm{N}^{\circ} 1$ ).

Tabla 1. Secuencia de iniciadores universales

\begin{tabular}{|c|c|}
\hline PRIMER & SECUENCIA \\
\hline ITS 1 & 5'-TCCGTAGGTGAACCTGCGG-3' $^{\prime}$ \\
ITS 2 & 5'-GCTGCGTTCTTCATCGATGC-3' \\
ITS 3 & 5'-GCATCGATGAAGAACGCAGC-3' \\
ITS 4 & 5'-TCCTCCGCTTATTGATATGC-3' \\
\hline
\end{tabular}

La reacción de PCR fue llevada a cabo en tubos de 1,5 mL de capacidad con un volumen final de $25 \mu \mathrm{L}$ que contenía: $1 \mu \mathrm{L}$ de DNA (60ng $/ \mu \mathrm{L}), 16,35 \mu \mathrm{L}$ de $\mathrm{H} 2 \mathrm{O}$ dd, 3 $\mu \mathrm{L}$ de $\mathrm{MgCl}_{2}(6 \mathrm{mM}), 2.5 \mu \mathrm{L}$ de Buffer (1X), $0.625 \mu \mathrm{L}$ de Primer A $(0.25 \mathrm{mM}), 0.625 \mu \mathrm{L}$ de Primer B $(0.25 \mathrm{mM}), 0.5 \mu \mathrm{L}$ de Taq pol, $0.4 \mu \mathrm{L}$ de DNTP`s $(0.2 \mathrm{mM})$. La reacción se llevó a cabo en un termociclador utilizando el siguiente programa: : $94^{\circ} \mathrm{C}$ por 2 minutos, para la desnaturalización inicial, seguido de 30 ciclos de 1 minutos por $94^{\circ} \mathrm{C}, 57^{\circ} \mathrm{C}$ por 1 minuto, $72^{\circ} \mathrm{C}$ por 1 minuto y una elongación final de $72^{\circ} \mathrm{C}$ por 10 minutos. Los amplificados fueron analizados por electorforesis en gel de azarosa al 0,8\% y se tiñó con Bromuro de etidio $(0,5 \mathrm{ug} / \mathrm{mL})$.

Amplificación de la región ITS mediante iniciadores específicos. El diagnóstico molecular específico para Mycosphaerella fijiensis mediante el ADN extraído a partir del micelio del hongo y del material vegetal infectado, se basó en la amplificación mediante PCR utilizando tres combinaciones posibles de iniciadores con sus condiciones de amplificación. (Tabla $\mathrm{N}^{\circ}$ 2).

Tabla 2. Secuencia de iniciadores específicos.

\begin{tabular}{|l|l|}
\hline Primer & Secuencia 5' 3 $^{\prime}$ \\
\hline R635 & GGTCCGTGTTTCAAGACGG \\
ITS 4 & TCCTCCGCTTATTGATATGC \\
MF 137 & GGCGCCCCCGGAGGTCTCCTT \\
\hline
\end{tabular}


Diagnóstico y caracterización molecular de Mycosphaerella fijiensis mediante la técnica de

La reacción de PCR fue llevada a cabo en tubos de $1,5 \mathrm{~mL}$ de capacidad con un volumen final de $25 \mu \mathrm{L}$ que contenía: $2,5 \mathrm{uL}$ Buffer (1X), 1,5 $\mu \mathrm{L}$ de $\mathrm{MgCl}_{2}(6 \mathrm{mM}), 2,5 \mu \mathrm{L}$ de DNTP`s $(0.2 \mathrm{mM}), 3 \mu \mathrm{L} /$ Cada primer $(0.2 \mathrm{mM}), 0,5 \mu \mathrm{L}$ de Taq pol, $5 \mu \mathrm{L}$ de ADN (60 ng/mL), $6.85 \mu \mathrm{L}$ de $\mathrm{H}_{2} \mathrm{O}$ dd. La reacción se llevó a cabo en un termociclador utilizando el siguiente programa: $94{ }^{\circ} \mathrm{C}$ por 5 minutos, para la desnaturalización inicial, seguido de 35 ciclos de 1 minuto a $94^{\circ} \mathrm{C}, 1$ minutos a $65^{\circ} \mathrm{C}$ y 2 minutos a $72^{\circ} \mathrm{C}$ y una elongación final de $72{ }^{\circ} \mathrm{C}$ por 5 minutos. Los amplificados fueron analizados por electorforesis en gel de agarosa al $0,8 \%$ y se tiñó con Bromuro de etidio $(0,5$ $\mathrm{ug} / \mathrm{ml})$.

Determinación de la variabilidad genética mediante el uso de la técnica RAPD. Para el método de RAPD`s se probaron 25 primers para la amplificación de la muestra, con las siguientes condiciones: La reacción se realizó en tubos eppendorf de $1,5 \mathrm{~mL}$ con un volumen final de $25 \mu \mathrm{L}$ que contenía: $5 \mu \mathrm{L}$ de Buffer (1X), $1 \mu \mathrm{L}(0.2 \mathrm{mM})$ de dNTP`s, $1,5 \mu \mathrm{L}$ de $\mathrm{MgCl}_{2}(6 \mathrm{mM}), 0,25 \mu \mathrm{L}$ de Taq pol, 37,25 $\mu \mathrm{L}$ de $\mathrm{H}_{2} \mathrm{O}$ dd, $4 \mu \mathrm{L}$ por decanucleótido $(0.2 \mathrm{mM})$ y $1 \mu \mathrm{L}$ de DNA $(60 \mathrm{ng} / \mu \mathrm{L})$. La reacción se llevó a cabo en un termociclador utilizando el siguiente programa: $94^{\circ} \mathrm{C}$ por 5 minutos, 44 ciclos de 6 minutos a $94^{\circ} \mathrm{C}, 1$ minutos a $36^{\circ} \mathrm{C}$, 2 minutos a $72^{\circ} \mathrm{C}$ y una elongación final de $72{ }^{\circ} \mathrm{C}$ por 10 minutos. Los amplificados fueron analizados por electorforesis en gel de agarosa al $0,8 \%$ y se tiñó con Bromuro de etidio $(0,5$ $\mathrm{ug} / \mathrm{mL}$ ).

\section{Resultados y discusión}

Obtención del material vegetal. Las muestras del material vegetal infectado por Sigatoka negra fueron obtenidas a partir de las recolecciones realizadas en los departamentos de Norte de Santander, Antíoquia y Santander (Tabla $\mathrm{N}^{\circ} 3$ ). Las muestras a trabajar deben encontrarse en los últimos estadios de la enfermedad (estadio 4, 5 y 6), donde se observa la presencia de los Peritecios, los cuales condicionan la formación de las ascosporas, importantes para el aislamiento de Mycosphaerella fijiensis.

Tabla 3. Aislamientos obtenidos a partir de las muestras recolectadas.

\begin{tabular}{|c|ccc|}
\hline$N^{\circ}$ Identificación & Departamento & Municipio & Finca \\
\hline Sigt 1 & Norte de Santander & Cúcuta & Granja ICA \\
Sigt 2 & Norte de Santander & Cúcuta & Granja ICA \\
Sigt 3 & Norte de Santander & Bochalema & Tolosa \\
Sigt 4 & Norte de Santander & Bochalema & Tolosa \\
Sigt 5 & Norte de Santander & Bochalema & Gutiérrez \\
Sigt 6 & Norte de Santander & Chinácota & Los álamos \\
Sigt 7 & Norte de Santander & El Diamante & Palermo \\
Sigt 8 & Norte de Santander & Los Patios & Bochalemita \\
Sigt 9 & Antioquia & Tarazá & Remolinos \\
Sigt 10 & Antioquia & Támesis & Nacional \\
Sigt 11 & Santander & Puerto Wilches & Atardecer \\
Sigt 12 & Santander & Barraza & Renacer \\
Sigt 13 & Mérida & Mérida & El Lago \\
\hline
\end{tabular}

Aislamiento del patógeno. Para el aislamiento del hongo, se trabajó con el método empleado y reportado por Stover en 1978, el cual establece un ambiente óptimo para las descargas de las ascosporas provenientes del material vegetal infectado. Duranteelprocesodeaislamientodel hongo Mycosphaerella fijiensis, se establecieron condiciones exigentes a nivel de laboratorio, que permitieran el crecimiento y desarrollo del micelio, previniendo la contaminación de este por otros agentes (Figura $\mathrm{N}^{\circ} 1$ ). Las acciones preventivas que se emplearon para esta primera parte de la metodología fueron el pretratamiento del tejido vegetal infectado, mediante lavados con agua estéril e hipoclorito de Sodio al 1,2\% con un tiempo de exposición de 1 minutos por cada lavado establecido.

Establecimiento de cultivos monospóricos. Para establecer los cultivos monospóricos de Mycosphaerella fijiensis, se empleó la metodología propuesta por Lopez (2004).

Para ello, se tomó una pequeña porción de los aislamientos con un asa estéril, transfiriendo la muestra a tubos de vidrio con un $1 \mathrm{~mL}$ de agua destilada previamente esterilizado y homogenizando con la ayuda de un vortex. Con ello se calculó la concentración de esporas $/ \mathrm{mL}$ 
mediante la cámara de Neubauer, dando una concentración promedio de 4 x 105 esporas/ $\mathrm{mL}$. Seguidamente, se realizaron los cálculos para obtener una solución con un volumen final de $1 \mathrm{~mL}$, y una concentración final de 1 espora/mL, mediante la fórmula C1x V1 = C2 x V2, Por Consiguiente, se tomó $10 \mathrm{uL}$ de la solución inicial y se pasó a un tubo con $1 \mathrm{~mL}$ de agua destilada estéril y se homogenizó con vórtex, visualizando mediante microscopía el micelio del patógeno. (Figura $\mathrm{N}^{\circ} 2$ ).

Figura 1. Mycosphaerella fijiensis.

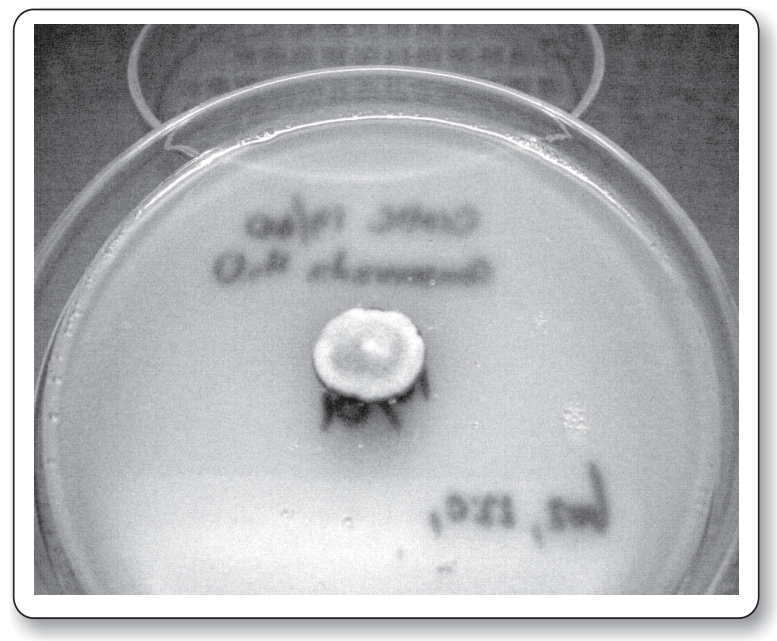

Figura 2. Microscopía del micelio M. fijiensis.

\section{Extracción del DNA}

Extracción de ADN a partir del micelio del hongo. Con respecto a la electroforesis en gel de agarosa del ADN total, se obtuvieron bandas de excelente calidad, sin degradación, ni presencia de RNAsas, lo cual confirma los buenos resultados con el protocolo de Sarmiento, I \& Angel, J. 2004.

Se observó una banda monomórfica en la electroforesis en gel de agarosa del ADN total extraído mostrando un peso de 42300 pb a partir del micelio de cada uno de los aislamientos obtenidos, como se observa en la figura $\mathrm{N}^{\circ} 3$.

Figura 3. Electroforesis en gel de agarosa de ADN total de Mycosphaerella fijiensis extraídos por el método de GOODWIN AND LEE en 1993, correspondiente a los aislamientos.

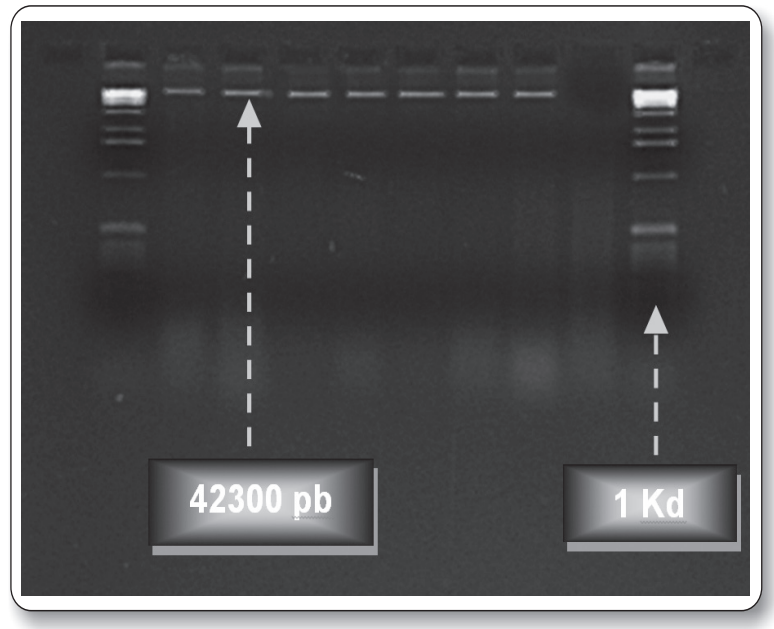

Extracción de $\mathrm{ADN}$ a partir del material vegetal infectado. Con respecto a la electroforesis en gel de agarosa del ADN extraído del tejido vegetal infectado, se obtuvieron bandas de excelente calidad, sin degradación, mi presencia de RNAsas, lo cual convierte al protocolo de Gilbertson and Dellaporta (Lopez, J, 2004) como una buena opción para la extracción de ADN a partir de material vegetal. Se observó una banda monomórfica en la electroforesis en gel de agarosa del ADN total extraído a partir de tejidovegetal infectado. Se estableciómediante el uso del marcador de peso molecular de $1 \mathrm{kd}$ ladder, el tamaño de las bandas obtenidas en la electroforesis, mostrando un peso de 47500 pb en cada una de ellas. (Figura $\mathrm{N}^{\circ} 4$ ). 
Diagnóstico y caracterización molecular de Mycosphaerella fijiensis mediante la técnica de

Figura 4. Electroforesis en gel de agarosa del ADN total extraído por el método de Gilbertson and Dellaporta modificado por el Lopez, 2004 a partir del tejido vegetal infectado.

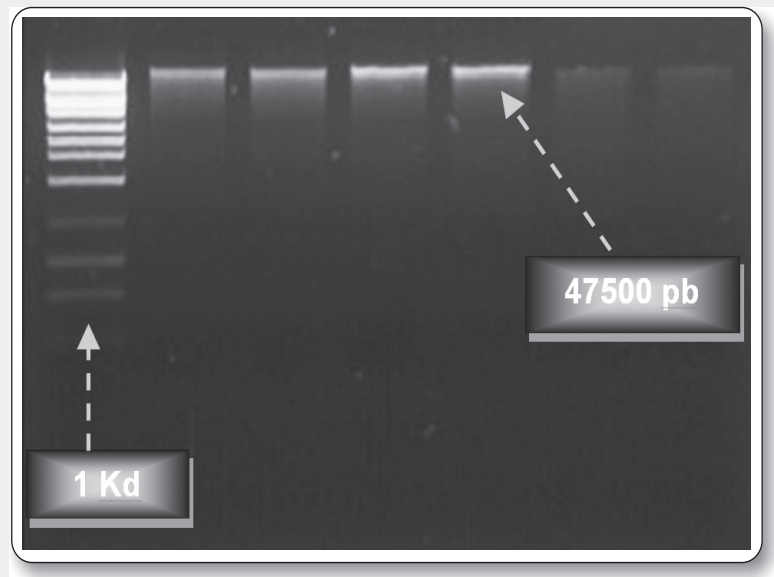

Amplificación de la región ITS mediante iniciadores universales

Figura 5. Electroforesis en gel de agarosa de productos de amplificación con iniciadores universales a partir de ADN de Mycosphaerella fijiensis. Los carriles corresponden a las siguientes amplificados: Carril 1: ITS A, Carril 2: Marcador de peso molecular de 100 pb, Carril 3: ITS B, Carril 4: ITS completo, Carril 5:

Control negativo.

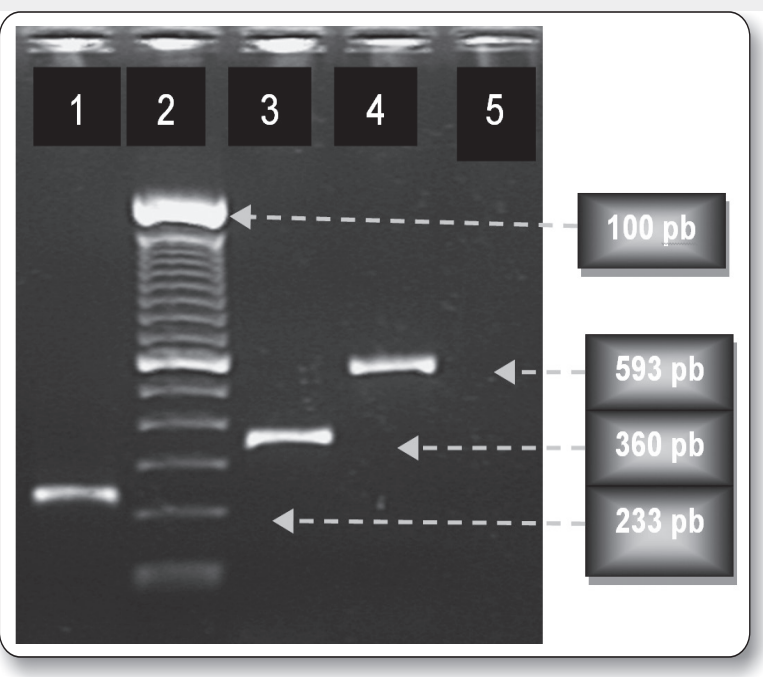

En la prueba diagnostica por PCR utilizando los iniciadores universales ITS 1 e ITS 2, se obtuvo un factor de amplificación de 233,0 $\mathrm{pb}$, denominando esta región ITS A (carril 1); ya que corresponde a la región amplificada entre el final de la subunidad $18 \mathrm{~S}$ y el inicio de la secuencia del gen $5,8 \mathrm{~S}$.
En la prueba de PCR utilizando los iniciadores universales ITS 3 e ITS 4, se obtuvo un factor de amplificación de 360,0 $\mathrm{pb}$, denominando esta región ITS B (carril 3); ya que corresponde a la región amplificada entre el final de la subunidad 5,8S y el inicio de la secuencia del gen 28 S.

Igualmente, para la prueba de PCR utilizando los iniciadores universales ITS 1 e ITS 4, se obtuvo un producto amplificado de 593,0 pb, denominando esta región ITS completo (carril 4); ya que corresponde a la región amplificada entre el final de la subunidad $18 \mathrm{~S}$ y el inicio de la región $28 \mathrm{~S}$. (Figura $\mathrm{N}^{\circ}$ 5)

\section{Amplificación de la región ITS mediante iniciadores específicos.}

Figura 6. Electroforesis en gel de agarosa de productos amplificados mediante oligonucleótidos específicos a partir de ADN extraído del micelio del hongo. Los carriles corresponden a los siguientes amplificados:

Carril 1: Aislamiento Norte de Santander

(Bochalema); Carril 2: Aislamiento Santander (Puerto Wilches); Carril 3: Marcador de peso molecular 100 pb; Carril 4: Aislamiento Mérida (Control positivo); Carril 5: Control negativo.

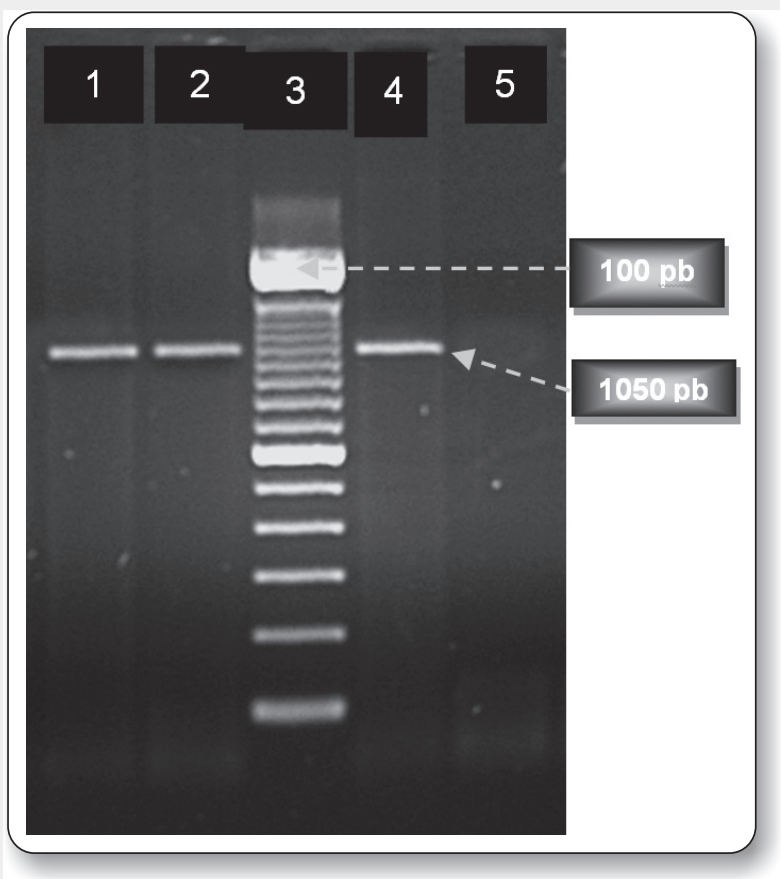


Diagnóstico y caracterización molecular de Mycosphaerella fijiensis mediante la técnica de amplificación aleatoria de polimorfismos (RAPD) y análisis de regiones transcriptos internos (ITS's)

específicos MF 137 y R635 generó un fragmento con un peso molecular de 1050 $\mathrm{pb}$, lo cual concuerda con las pruebas realizadas por Charry, C. 2002, quien practicó el diagnóstico molecular a Mycosphaerella fijiensis, obteniendo los pesos específicos de la banda entre 1000 pb a 1080 pb, utilizando los iniciadores MF 137 y R635; y una banda de 500 a 580 pb, usando los iniciadores MF 137 e ITS 4. (Figura $\mathrm{N}^{\circ} 6$ ).

Figura 7. Amplificación con iniciadores específicos a partir de ADN extraído del material vegetal infectado. Los carriles corresponden a los siguientes amplificados:

Carril 1: Marcador de peso molecular de $100 \mathrm{pb}$;

Carril 2: Material vegetal de Norte de Santander (Chinácota); Carril 3: Aislamiento Mérida (Control positivo); Carril 4: Control negativo.

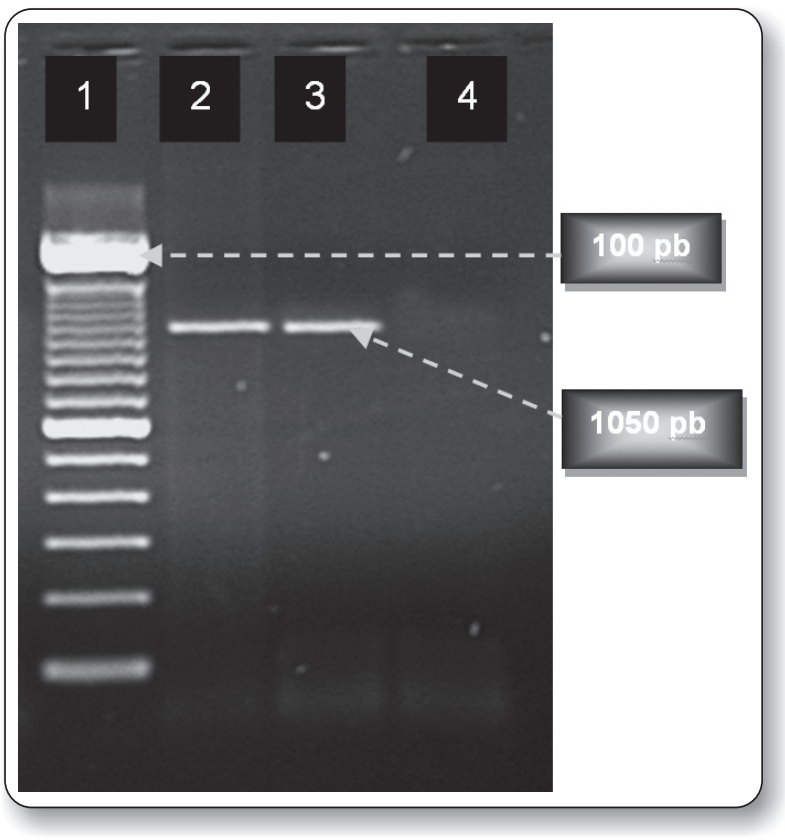

Secomprobólasensibilidadylaespecificidad de los iniciadores MF 137 y R635 utilizados para el diagnóstico de Mycosphaerella fijiensis en el ADN extraído a partir de tejido vegetal infectado, ya que, la muestra de ADN usada para la amplificación contenía ADN total, en otras palabras, presentaba genomas de otros agentes externos al objeto de estudio. (Figura $\mathrm{N}^{\circ} 7$ ).

Determinación de la variabilidad genética mediante el uso de la técnica RAPD. Luego de evaluar los 25 iniciadores propuestos, se obtuvieron ocho (8) productos de amplificación positivos para los aislamientos de Mycosphaerella fijiensis. (Tabla $\mathrm{N}^{\circ} 4$ ).

Tabla 4. Oligonucleótidos positivos para Mycosphaerella fijiensis

\begin{tabular}{|c|c|}
\hline Primer & Secuencia $\mathbf{5}^{\prime}-\mathbf{3}^{\prime}$ \\
\hline OPA2 & TGCCGAGCTG \\
OPA 3 2 & AGTCAGCCAC \\
OPC 5 & GTGAGGCGTC \\
OPC 8 & TGGACCGGTG \\
OPC 10 & GTGAGGCGTC \\
OPC 11 & AAAGCTGCGG \\
OPH 14 & GAGCCCTCCA \\
\hline
\end{tabular}

Figura 8. Análisis electroforético de los productos de RAPD's utilizando el oligonucleótido OPC 5.

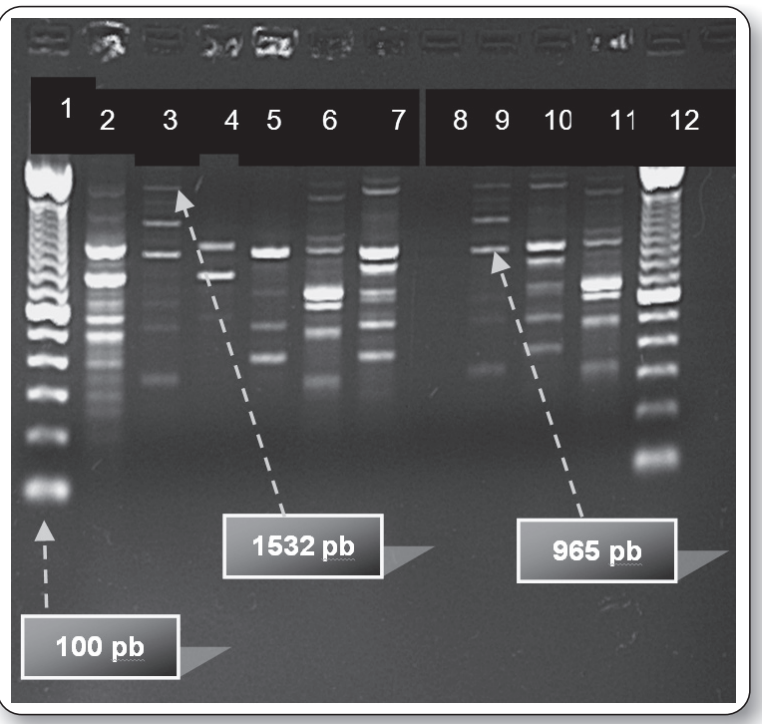

En el análisis bioinformático de los aislamientos de la figura $\mathrm{N}^{\circ} 8$ con el primer OPC 5, se observa un claro patrón de semejanza entre los amplificados de Bochalema (Carril 3 
y Carril 9), los de Santander (Carril 4 y 5) y los de Antioquia (Carril 2 y 11), lo cual significa alta similitud entre los genomas estudiados.

Se observó una banda común en los aislamientos $2,3,5,6,7,9,10$ y 11 con peso molecular aproximado de $965 \mathrm{pb}$, figura $\mathrm{N}^{\circ}$ 8; igualmente, los aislamientos $2,3,6,7$, 9 y 10 comparten una banda con un peso aproximado de $1532 \mathrm{pb}$, Figura $\mathrm{N}^{\circ} 8$, siendo aislamientos de diferentes regiones del país.

\section{Análisis estadístico}

Figura 9. Dendograma de similitud DICE - UPGMA.

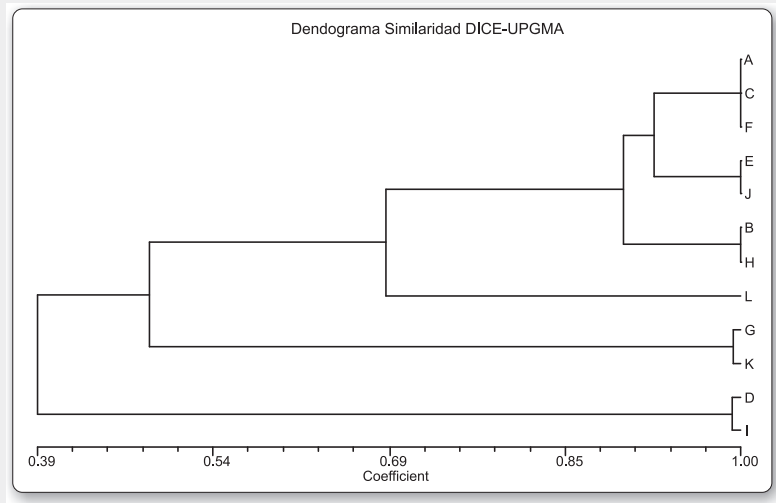

El resultado obtenido en la construcción del dendograma presentó que los aislamientos de Mycosphaerella fijiensis del Departamento Norte de Santander (A, C, F, E, J), generaron un agrupamiento, con un porcentaje de similaridad de 90\%. Igualmente el aislamiento obtenido de Mérida Venezuela (L) usado como Control positivo, presentó un porcentaje de similaridad del 70\%, confirmando las cercanías genéticas de los aislamientos de Norte de Santander con el aislamiento de Mérida. Los otros aislamientos presentaron una similaridad genética de $48 \%$ y $35 \%$ correspondientes a los Departamentos de Santander (G, K) y Antioquía (D, I) respectivamente. (Figura $N^{\circ}$ 9).

\section{Conclusiones}

Es importante que las muestras foliares utilizadas para el aislamiento de Mycosphaerella fijiensis se encuentren en los últimos estadios de la enfermedad, ya que, en estos ultimas etapas se desarrolla el ascocarpo denominado peritecio, el cual contienen las ascosporas usadas para el proceso de aislamiento del patógeno.

Los productos amplificados de las regiones ITS`s universales de Mycosphaerella fijiensis obtenidas, generaron un fragmento de 233 pb (ITS A), un fragmento de $360 \mathrm{pb}$ (ITS B) y un producto de $593 \mathrm{pb}$ (ITS Completo), siendo esta información muy importante para desarrollar nuevas secuencias de iniciadores para la detección específica del patógeno.

Se estableció una prueba estándar a nivel molecular mediante iniciadores específicos de M. fijiensis para el diagnóstico de este patógeno a partir del micelio del hongo. Los iniciadores MF 137 y R635 generaron un fragmento con un peso molecular de $1050 \mathrm{pb}$, lo cual concuerda con las pruebas realizadas por Charry, 2002, quien practicó el diagnóstico molecular a M. fijiensis, obteniendo los pesos específicos de la banda entre $1000 \mathrm{pb}$ a $1080 \mathrm{pb}$.

Se comprobó la sensibilidad y la especificidad de los iniciadores MF 137 y R635 utilizando el ADN extraído del tejido vegetal infectado, obteniendo un fragmento con un peso molecular de $1050 \mathrm{pb}$. Con esta amplificación se aportó nuevas herramientas para la detección de M. fijiensis, reflejada en la disminución en el tiempo del proceso de detección comparada con la diagnosis molecular a partir del micelio del hongo.

Los productos amplificados de RAPD`s, generaron patrones de semejanza genómicos entre los aislamientos obtenidos de los Departamentos de Norte de Santander, Mérida. Antioquia y Santander. Se presentó un total de 460 bandas, promediando por cada iniciador polimórfico 57 bandas amplificadas, evidenciando la gran variabilidad genética presentada por Mycosphaerella fijiensis en cada una de las muestras estudiadas. Los rangos de tamaño en los fragmentos obtenidos en el estudio estuvieron entre $380 \mathrm{pb}$ a $2115 \mathrm{pb}$. 
La visualización de diferentes bandas en los geles permitió elaborar una matriz de presencia ausencia de las mismas; dicha matriz binaria se transfirió al programa NTSYS (Numerical Taxonomic and Multivariate Análisis System), versión 1.8 diseñado por Rohlf, 1984 para crear la matriz de similitud mediante el cálculo del coeficiente de Dice. La matriz resultante se analizó con el algoritmo UPGMA (Unweighted Pair Group Method with Arithmatic Mean) para la construcción del dendrograma.

El resultado obtenido en la construcción del dendograma, presentó una diferenciación marcada entre los aislamientos de cada Departamento con respecto al control positivo (Aislamiento Mérida). En Norte de Santander la similaridad genética fue de un $90 \%$, la de Mérida fue de un 70\%, en Santander de un 48\% y Antioquía de un 35\%.

\section{Agradecimientos}

Al personal del Instituto Colombiano Agropecuario por su colaboración para la realización de esta investigación científica.

\section{Bibliografía}

AGRIOS, G. 1996. Fitopatología. Editorial Limusa Noriega. 2da Edición, México.

CASTIBLANCO, $\mathrm{N}$ and ANGEL, J. 2004. Caracterización molecular y análisis polimórfico de aislamiento de Rhizoctonia solani, provenientes del cultivo de la papa en Cundinamarca y Nariño. ICA INFROMA. Vol 25 pág $12-25$.

CHARRY, C. 2001. Comparación entre dos métodos diagnostico basados en técnicas de biología molecular para la identificación de Mycosphaerella fijiensis. Trabajo de grado. Universidad Javeriana. Bogotá.

GRISALES, F. 1997. La Sigatoka Negra y la producción del plátano en la zona cafetera central de Colombia. Revista Cenicafé. Vol 2, pág $5-9$.

LOPEZ, J. 2004. Determinación de la variabilidad genética entre aislamientos de Rosellinia pepo y Rosellinia bunodes mediante la Técnica de amplificación aleatoria de polimorfismos DNA (RAPD) y análisis de espaciadores internos (ITS).

RUIZ, S. 1997. Efecto en el crecimiento de Mycosphaerella fijiensis mediante el uso de diferentes sustratos y medios de cultivo. Tesis de grado. España. Pág 120.

SARMIENTO, I \& ANGEL, J. 2004. Análisis y caracterización molecular de polimorfismos genéticos en aislamientos de Rosellinia sp., procedentes de tres zonas productoras de papa. ICA INFORMA. 25: 8 - 14 .

STOVER, R. 1962. Intercontinental Spread of banana leaf spot Mycosphaerella fijiensis. Tropical Agriculture. 39: 327 - 338.

STOVER, R. 1968. Leaf spot of bananas caused by Mycosphaerella fijiensis: Perithecia and sporodochia production in different climates. Tropical Agriculture, 45: 234 - 256.

STOVER, R. 1978. Distribution and cultural characteristics of the pathogens causing banana leaf spot. Tropical Agriculture, 53: $110-114$.

UNIVALLE - UPEC. 2001. Banana leaf spot (Mycosphaerella fijiensis) on the FHIA I variety in Colombia. Revista Agrícola Univalle. 16:18 - 25 . 